Article

\title{
An Analysis of the Emission Reduction Targets of "Belt and Road" Countries Based on Their NDC Reports
}

\author{
Jing $\mathrm{Wu}^{1,2}$, Guan Kaixuan ${ }^{1}$, Qianting Zhu ${ }^{3}$, Wang Zheng ${ }^{1,2,4}$, Yuanhua Chang ${ }^{3}$ and \\ Xiong Wen ${ }^{5, *}$ \\ 1 Institutes of Science and Development, Chinese Academy of Sciences, Beijing 100190, China; \\ wujing@casisd.cn (J.W.); gkx0831@163.com (G.K.); wangzheng@casipm.ac.cn (W.Z.) \\ 2 School of Public Policy and Management, University of Chinese Academy of Sciences, Beijing 100049, China \\ 3 School of Economics and Management, China University of Petroleum, Beijing 102249, China; \\ eteng0122@foxmail.con (Q.Z.); yhchang@cup.edu.cn (Y.C.) \\ 4 School of Geography, East China Normal University, Shanghai 200062, China \\ 5 School of Economics, Beijing Technology and Business University, Beijing 100048, China \\ * Correspondence: hsiongwell@foxmail.com
}

Received: 14 October 2019; Accepted: 4 December 2019; Published: 9 December 2019

\begin{abstract}
The emission reduction targets articulated in the nationally determined contribution (NDC) reports of the "Belt and Road" countries, which have joined China in an international alliance to promote green development, are studied in this paper. Our findings indicate that the most commonly adopted emission reduction targets are relative to emissions in the base year and to baseline scenarios. Approximately half of these countries request technological and financial support from the international community in their NDC reports. Greenhouse gas inventory accounting, and data management, modeling, and tools are the most commonly identified technological needs. Moreover, the NDC reports indicate that $\$ 2.88$ trillion of financial support is explicitly required, while a reliable international financial assistance and technology transfer would enable considerably higher emission reduction targets to be reached in Belt and Road countries. Our analysis of the top four emitters among these countries reveal a future decreasing trend for China and Russia and an increasing trend for India and Indonesia. China can effectively promote its Belt and Road green development initiative through measures such as capacity building in the areas of emission inventory accounting, constructing an "Internet Plus" platform for the use and management of low-carbon data, and technology exchanges aimed at strengthening low-carbon development.
\end{abstract}

Keywords: belt and road initiative; emission reduction; climate change; nationally determined contribution

\section{Introduction}

More than 190 countries have articulated their nationally determined contributions (NDCs), mandated in the Paris Agreement and entered into force in 2016. Emission reductions have been incorporated within a new bottom-up governance model at the global scale. In particular, countries that are part of the "Belt and Road" initiative are most affected by climate change. These countries, which are major emitters of greenhouse gases (GHGs), therefore play an important role in climate change negotiations [1]. According to the International Energy Agency (IEA), the Belt and Road countries, including China, collectively accounted for approximately 50\% of global energy consumption and approximately $54 \%$ of global carbon emissions in 2014 . Therefore, the promotion of an ecological civilization across these countries has become imperative. On 14 May 2017, at the "Belt and Road" forum 
for international cooperation, the Chinese government proposed the initiative of the international alliance of the "Belt and Road" green development, which aims to create a green, low-carbon, and sustainable economic development model. As of 5 January 2018, all the 64 Belt and Road countries (The 64 Belt and Road countries are Mongolia, Iran, Iraq, Turkey, Jordan, Lebanon, Israel, Palestine, Saudi Arabia, Yemen, Oman, United Arab Emirates, Qatar, Kuwait, Bahrain, Greece, Cyprus, Egypt, India, Pakistan, Bangladesh, Afghanistan, Sri, Lanka, Maldives, Nepal, Bhutan, Kazakhstan, Uzbekistan, Turkmenistan, Tajikistan, Kyrgyzstan, Singapore, Malaysia, Indonesia, Myanmar, Thailand, Laos, Cambodia, Vietnam, Brunei, the Philippines, Russia, Ukraine, Belarus, Georgia, Azerbaijan, Armenia, Moldova, Poland, Lithuania, Estonia, Latvia, Czech Republic, Slovakia, Hungary, Slovenia, Croatia, Bosnia and Herzegovina, Montenegro, Serbia, Albania, Romania, Bulgaria, and Macedonia. This study focuses on the NDC reports of all of the Belt and Road countries apart from China), with the exception of Syria, had submitted the relevant documents on their emission reduction contributions. To ascertain the direction and key features of the Belt and Road green development initiative, it is necessary first to extract the emission reduction strategies, technical and financial requirements, and other considerations relating to emission reduction from the NDC reports submitted by each of the Belt and Road countries.

The NDC assessments are currently attracting the attention of researchers that focus on national climate policies [2]. In particular, future emission reduction targets and emission pathways derived from NDC reports have emerged as a major research topic globally [3-7]. However, to date, there has been no comprehensive study conducted on the NDCs of the Belt and Road countries, with most analyses focusing on the characteristics of historical carbon emissions in these countries. Fan et al. (2019) posited that economic development and energy consumption are the main drivers of the growth in carbon emissions in the Belt and Road countries [8]. Using normal regression and quantile regression methods, Fu and Si (2017) analyzed factors driving carbon emissions in 50 Belt and Road countries during the period 1992-2011 [9]. Wu et al. (2018) tested the environmental Kuznets curve (EKC) hypothesis for the Belt and Road countries, focusing on per capita energy consumption, per capita carbon dioxide emissions, and per capita GDP for the years 2006, 2009, and 2014 [10]. Applying Hofstede's cultural dimensions theory, $\mathrm{Xu}$ and $\mathrm{Wu}$ (2018) studied the impacts of cultural dimensions on carbon emissions in 42 Belt and Road countries [11]. They applied the EKC as a theoretical framework to develop a dynamic panel measurement model for culture and carbon emissions. Liu and Hao (2018) performed a causality test to analyze dynamic relations among energy consumption, economic growth, and carbon emissions in the Belt and Road countries [12]. Thus, all the above studies explored the possibility of reducing emissions in the Belt and Road countries from the perspective of historical carbon emissions, but they discounted the fact that emissions reductions are still significantly affected by national emission reduction policies. The NDC report of each country would give us an insight into the willingness of countries to reduce their emissions and adapt to their actions, so as to provide a reference for China to implement the "Belt and Road" green development initiative.

We examined the current situation of carbon emissions in 61 Belt and Road countries, focusing on their NDC reports. Specifically, we examined their emission reduction strategies, interests and demands, and emission trends. In the summary section, we offer recommendations on appropriate policies for advancing the Belt and Road green development initiative.

\section{The Characteristics of GHG Emissions in the Belt and Road Countries}

We will first examine historical emission data for the Belt and Road countries to obtain an overview of the emission characteristics of these countries before presenting an analysis of their NDC reports. The data used in this paper were obtained from the World Resources Institute [13]. A lack of available data led to the exclusion of four countries, namely Syria, Palestine, Bulgaria, and Montenegro, from the analysis. Thus, we examined emissions data obtained for 61 Belt and Road countries.

As shown in Figure 1, the GHG emissions of the 61 Belt and Road countries first decreased and then increased during the period 1990-2014 at an annual rate of increase of 1.85\%. Notably, GHG 
emissions have been rising from 10,627.14 $\mathrm{MtCO}_{2} \mathrm{e}$ in 2000 to $14,819.92 \mathrm{MtCO}_{2} \mathrm{e}$ in 2014, reflecting an increase of $39.45 \%$. However, since 2000, the proportion of GHG emissions from the Belt and Road countries to the world's total GHG emissions has exhibited an increase from $28.3 \%$ in 2000 to $30.3 \%$ in 2014. Figure 2 reveals a significant acceleration in the GDP growth rates of Belt and Road countries since 2000. However, the GDPs of these countries collectively accounted for just $17.3 \%$ of the global GDP value in 2014, a figure that is considerably lower than the proportion of GHG emissions during 2000 to 2014. These data indicate that the Belt and Road countries demonstrate higher emission intensities and weaker green economies compared with the respective global averages (Figure 3). Though the carbon intensity of the Belt and Road countries experienced a continuous decline between 1990 and 2014, the carbon intensity in 2014 was still two times the world's average. Consequently, the establishment of an international alliance to promote green development is aimed at strengthening the capacities of Belt and Road countries to enable them to develop green economies.

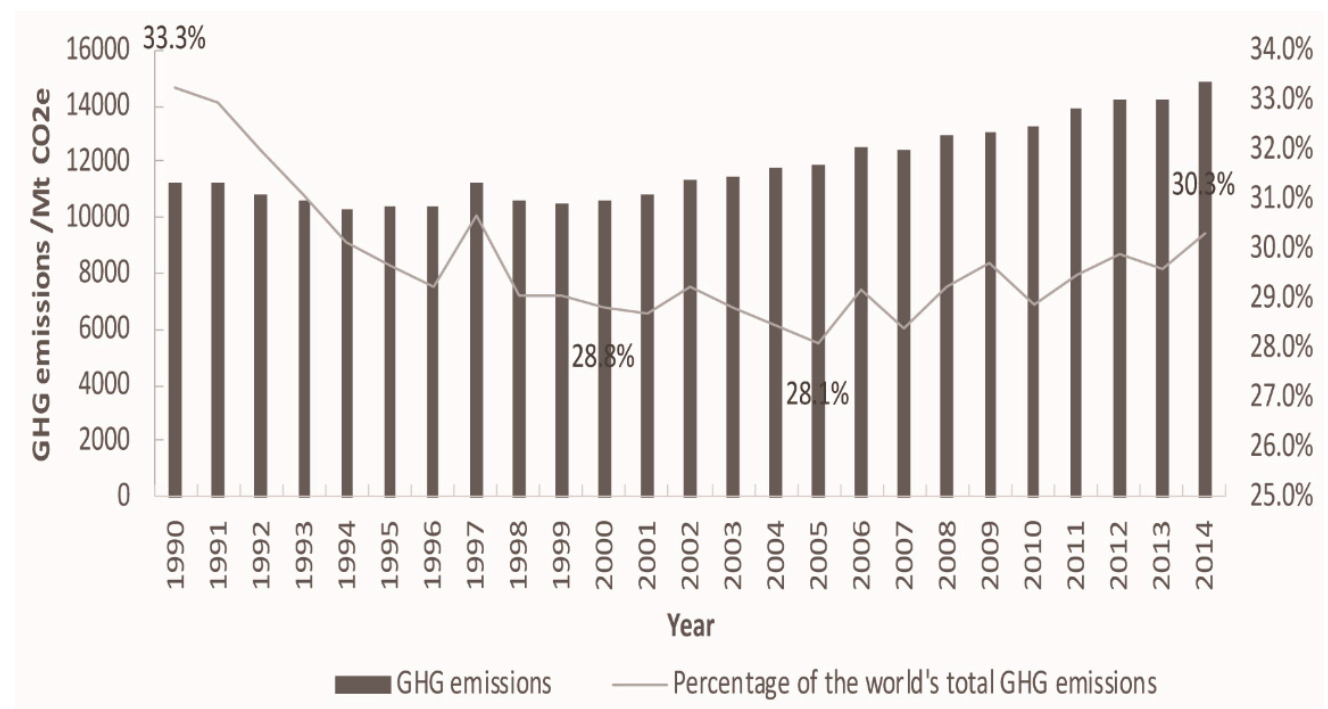

Figure 1. The total greenhouse gas emissions of 61 Belt and Road countries.

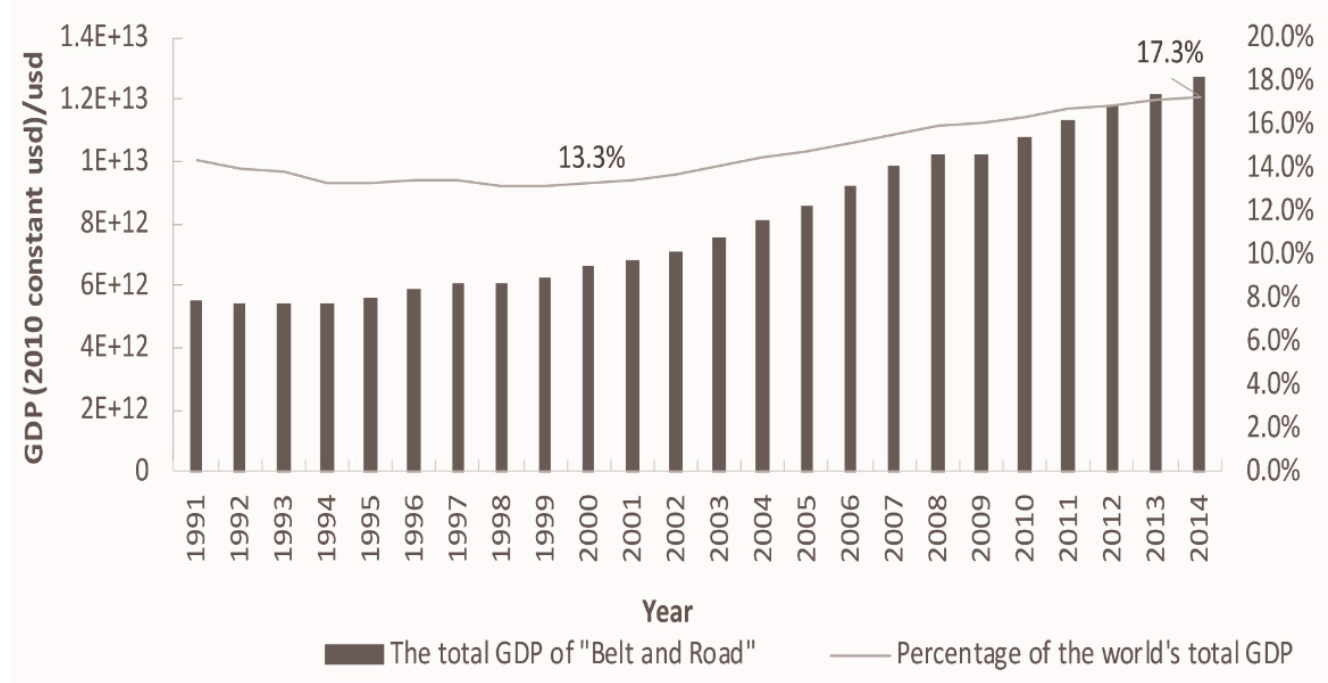

Figure 2. The GDP growth rates of 61 Belt and Road countries. 


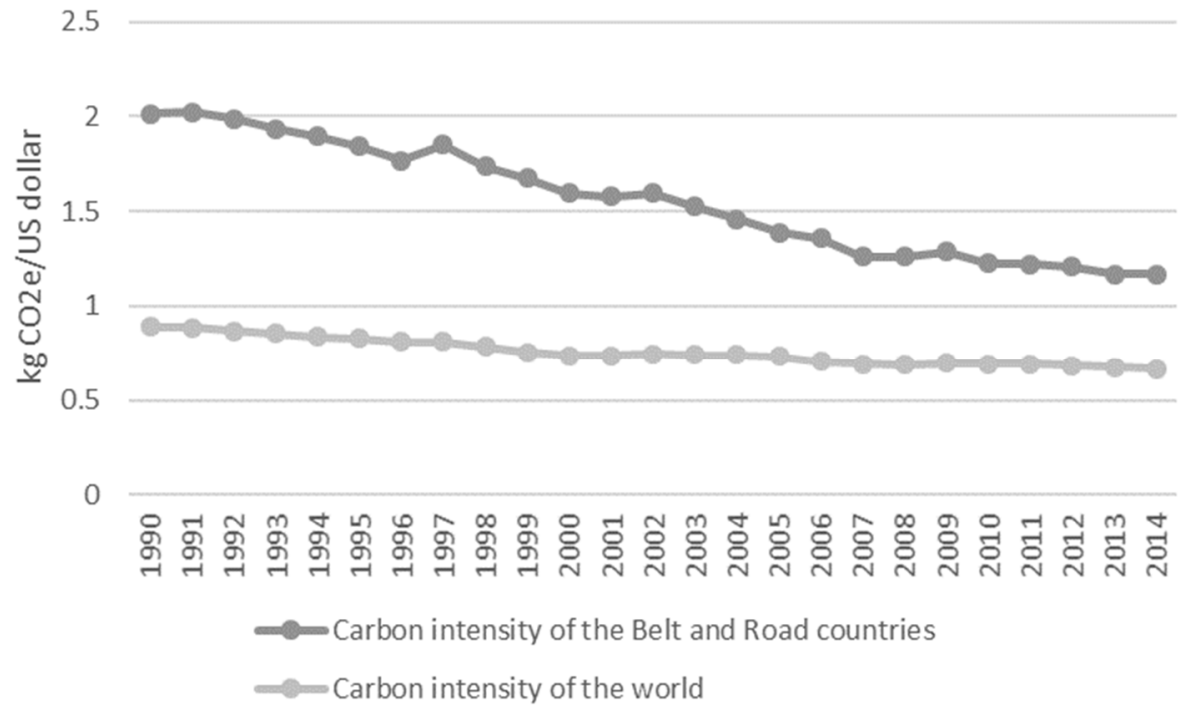

Figure 3. Comparison of averaged carbon intensity between the Belt and Road countries and the world.

Due to differences in the levels of economic development and the resource endowments of the 61 Belt and Road countries, their GHG emissions showed significant variations during the period 1990-2014. Figure 4 shows the top 10 and the bottom 10 Belt and Road countries in terms of GHG emissions. The total emissions of the bottom 10 countries were evidently at very low levels. Romania and Bhutan even demonstrated negative GHG emissions in 2014 because of their extensive forest coverage. The top 10 GHG-emitting countries (India, Indonesia, Russia, Iran, Saudi Arabia, Thailand, Turkey, Pakistan, Ukraine, and Poland) contributed significantly to GHG emissions. These countries include developing countries that are attempting to advance their economic development as well as high-income Middle Eastern oil-producing countries. In 2014, the total emissions of the top 10 countries reached $10,863.05 \mathrm{MtCO}_{2} \mathrm{e}$, accounting for $73.3 \%$ of the total emissions of all 61 Belt and Road countries. However, in 2014, the total GDP of the top 10 countries accounted for $64.3 \%$ of the total GDP of these 61countries, indicating that the GHG emissions efficiency is lower for these countries than for the remaining 51 countries.
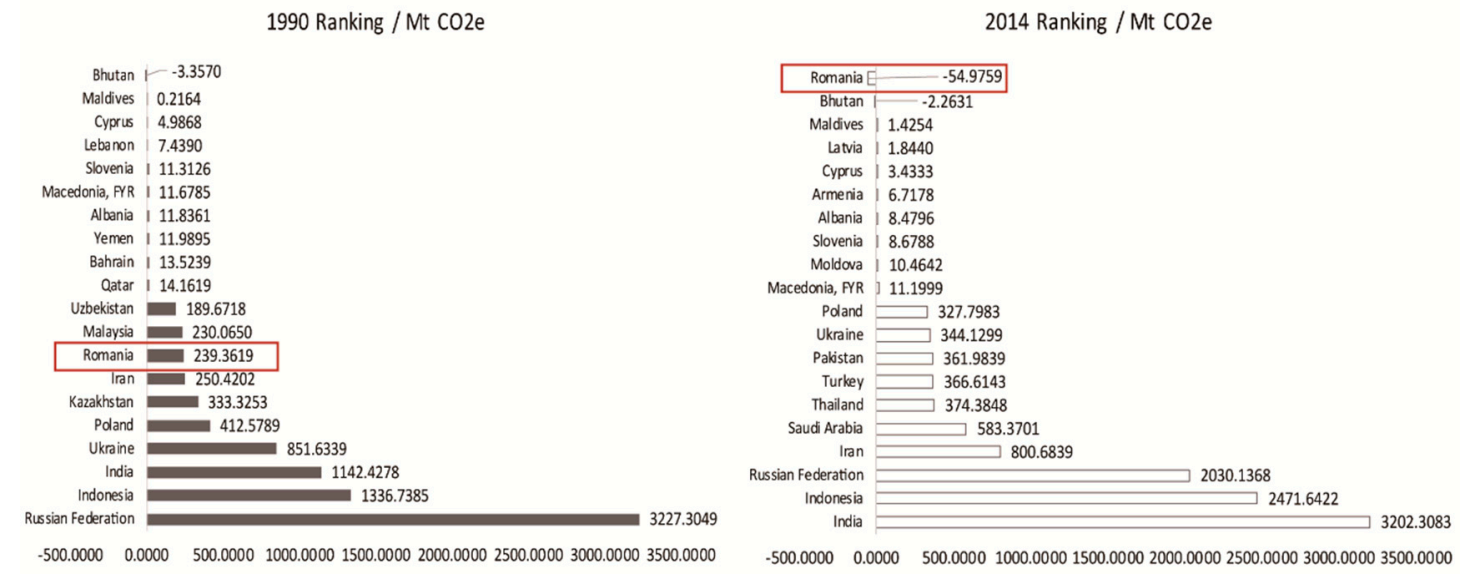

Figure 4. The top 10 and bottom 10 Belt and Road countries ranked in terms of their GHG emissions.

The low emission efficiency was particularly evident for India, Indonesia, and Russia, which are also the top three GHG emitters among the Belt and Road countries. The GHG emissions of these three countries collectively reached $7704.09 \mathrm{MtCO}_{2} \mathrm{e}$, accounting for $51.98 \%$ of the total emissions of the Belt and Road countries in 2014. However, the combined GDPs of these three countries only accounted for 
$37.46 \%$ of the total GDP of the Belt and Road countries, indicating that the emission efficiency of those countries is very low. However, in 2014, the GDP growth rates of India and Indonesia increased 3.56 and 2.01 times above their 1990 levels, respectively, while their GHG emissions also increased 2.8 and 1.9 times, respectively, during this period. The increasing rates of GDP and GHG emissions in India and Indonesia can be attributed to processes of urbanization and industrialization during a period of rapid economic growth [14-16]. Russia's GHG emissions in 2014 showed a decline by 37\% from their levels in 1990, which is closely aligned with the economic recession that followed the collapse of the Soviet Union in 1990. Being among the top GHG-emitting Belt and Road countries, these three countries are facing strong pressures relating to their emissions and have considerable potential to reduce them. Their willingness to reduce their emissions is thus a crucial factor.

Overall, the Belt and Road countries are characterized by rising GHG emissions and low emission efficiency. In addition, future efforts to reduce GHGs made by the top 10 GHG-emitting countries, especially India, Indonesia, and Russia, will be of critical importance.

\section{An Analysis of Mitigation Targets}

\subsection{Categorization of Emission Reduction Targets}

Due to differences in economic, social, political, and resource endowments, emission reduction targets, as stated in the NDCs of Belt and Road countries, also vary. Six categories of GHG mitigation targets were identified based on the NDC reports of the 64 Belt and Road countries: emission reductions relative to base year targets, emission reductions relative to baseline scenario targets, fixed level targets, emission intensity targets, trajectory targets, and policy action. Each of these is discussed in turn below.

\section{(1) Emission reductions relative to base year targets}

The results of the analysis indicated that 22 countries, including Russia, the Czech Republic, Estonia, Greece, Hungary, Latvia, Lithuania, Poland, Romania, and Serbia adopted emission reduction targets relative to base year emissions (Table 1). On the whole, these 22 countries are relatively high or middle income.

Greece, Hungary, and other European Union countries have set emission reduction targets relative to 1990. Countries affiliated with the former Soviet Union, such as Belarus and Ukraine, which have also chosen emission reductions targets of $30 \%$ to $40 \%$ relative to 1990, which suggests a greater willingness to reduce emissions.

Most countries have set emission reduction levels at $30 \%$, with those of the remaining countries ranging between $9.8 \%$ and $78 \%$. Serbia, which only committed to a $9.8 \%$ reduction in its emissions compared with its 1990 levels, had the lowest emission reduction ratio. In contrast, Moldova had the highest emission reduction ratio, promising unconditionally to reduce its emissions by $64 \%$ to $67 \%$ in 2030 compared with its 1990 levels. 
Table 1. The emission reduction targets of Belt and Road countries relative to the base year (1990).

\begin{tabular}{|c|c|c|c|c|}
\hline Country & Base Year & Target Year & Reduction Ratio & Income Group ${ }^{1}$ \\
\hline Azerbaijan & 1990 & 2030 & $35 \%$ & $\begin{array}{l}\text { Upper middle } \\
\text { income }\end{array}$ \\
\hline Belarus & 1990 & 2021-2030 & $28 \%$ & $\begin{array}{l}\text { Upper middle } \\
\text { income }\end{array}$ \\
\hline Bulgaria & 1990 & 2030 & $30 \%$ & $\begin{array}{l}\text { Upper middle } \\
\text { income }\end{array}$ \\
\hline Croatia & 1990 & 2030 & $30 \%$ & High income \\
\hline Cyprus & 1990 & 2030 & $30 \%$ & High income \\
\hline Czech Republic & 1990 & 2030 & $30 \%$ & High income \\
\hline Estonia & 1990 & 2030 & $30 \%$ & High income \\
\hline Greece & 1990 & 2030 & $30 \%$ & High income \\
\hline Hungary & 1990 & 2030 & $30 \%$ & High income \\
\hline Kazakhstan & 1990 & 2021-2030 & $\begin{array}{l}\text { Unconditional: } \\
\text { 15\% conditional: } \\
25 \%\end{array}$ & $\begin{array}{l}\text { Upper middle } \\
\text { income }\end{array}$ \\
\hline Latvia & 1990 & $2021-2030$ & $40 \%$ & High income \\
\hline Lithuania & 1990 & 2030 & $30 \%$ & High income \\
\hline Moldova & 1990 & 2021-2030 & $\begin{array}{c}\text { unconditional: } \\
64-67 \% \\
\text { conditional: } 78 \%\end{array}$ & $\begin{array}{l}\text { Lower middle } \\
\text { income }\end{array}$ \\
\hline Montenegro & 1990 & 2030 & $30 \%$ & $\begin{array}{c}\text { Upper middle } \\
\text { income }\end{array}$ \\
\hline Poland & 1990 & 2030 & $30 \%$ & High income \\
\hline Romania & 1990 & 2030 & $30 \%$ & $\begin{array}{l}\text { Upper middle } \\
\text { income }\end{array}$ \\
\hline $\begin{array}{c}\text { Russian } \\
\text { Federation }\end{array}$ & 1990 & 2020-2030 & $25-30 \%$ & $\begin{array}{c}\text { Upper middle } \\
\text { income }\end{array}$ \\
\hline Serbia & 1990 & $2021-2030$ & $9.8 \%$ & $\begin{array}{l}\text { Upper middle } \\
\text { income }\end{array}$ \\
\hline Slovakia & 1990 & 2030 & $30 \%$ & High income \\
\hline Slovenia & 1990 & 2030 & $30 \%$ & High income \\
\hline Tajikistan & 1990 & 2021-2030 & $\begin{array}{c}\text { unconditional: } \\
\text { 10-20\% conditional: } \\
25-35 \%\end{array}$ & Low income \\
\hline Ukraine & 1990 & 2021-2030 & $40 \%$ & $\begin{array}{l}\text { Lower middle } \\
\text { income }\end{array}$ \\
\hline
\end{tabular}

\footnotetext{
${ }^{1}$ Based on World Bank income classification: http://databank.worldbank.org/data/download/site-content/CLASS.xls.
}

\section{(2) Emission reductions relative to baseline scenario targets}

As shown in Table 2, 23 countries, including Bangladesh, Brunei, Cambodia, Indonesia, Iran, Iraq, Jordan, Palestine, the Philippines, Sri Lanka, Thailand, Turkey, Vietnam, and Afghanistan have adopted emission reduction targets relative to a BAU scenario. The majority of these 22 countries are not high-income countries, and their GHG emissions are mainly composed of $\mathrm{CO}_{2}$ and $\mathrm{CH}_{4}$.

The emission reduction commitments of these countries showed significant variation. Most of them have made commitments to reduce their emission reductions by less than $20 \%$, which is evidently lower than that of countries adopting emission reductions relative to the base year. However, the 
emission reduction targets of Brunei, the Philippines, and Cambodia, which ranged between $60 \%$ and $70 \%$ relative to their baseline scenario emissions, far exceeded those of other countries. These three countries are highly vulnerable to climate change and are therefore strongly motivated to reduce emissions. In addition, countries whose emission reduction targets are relative to their baseline scenario emissions are more likely to propose two emission reduction targets under conditional and unconditional scenarios, respectively. As shown in Table 2, the NDC reports of 16 out of the 22 countries mentioned that if more aid and technical support were available, the proportions of their emission reductions would increase. This finding suggests that countries with relatively lower financial endowments tend to choose emission reduction targets relative to their baseline scenario, while emphasizing the importance of international aid and technical support.

Table 2. Belt and Road countries with emission reduction targets relative to their business as usual (BAU) states.

\begin{tabular}{|c|c|c|c|}
\hline Country & Target Year & Reduction Ratio & Income Group \\
\hline Afghanistan & 2030 & $13.60 \%$ & Low income \\
\hline Albania & $2016-2030$ & $11.5 \%$ & Upper middle income \\
\hline Bengal & $2020-2030$ & unconditional: $5 \%$, conditional: $15 \%$ & Lower middle income \\
\hline Bosnia & 2030 & unconditional: $2 \%$, conditional: $3 \%$ & Upper middle income \\
\hline Brunei & $2021-2030$ & $\begin{array}{l}\text { (1) energy industry: energy consumption } \\
\text { reduced by } 63 \% 63 \% \text { (BAU) renewable energy } \\
\text { accounts for } 10 \% \text { of total energy (2) land } \\
\text { transport sector: } 40 \% \text { reduction in } \mathrm{CO}_{2} \\
\text { emissions (BAU) (3) forest coverage reaches } \\
55 \% \text {, an increase of } 34 \% \text { (baseline current value, } \\
2015 \text { ) }\end{array}$ & High income \\
\hline Cambodia & 2030 & $\begin{array}{l}\text { unconditional: } 27 \% \text { conditional: forest } \\
\text { coverage reaches } 60 \% \text {, LULUCF reduces } \\
\text { emissions by } 57 \%\end{array}$ & Lower middle income \\
\hline Georgia & 2021-2030 & unconditional: $15 \%$, conditional: $25 \%$ & Upper middle income \\
\hline Indonesia & 2030 & unconditional: $29 \%$, conditional: $41 \%$ & Lower middle income \\
\hline Iran & $2021-2030$ & unconditional: $4 \%$, conditional: $8 \%$ & Upper middle income \\
\hline Iraq & 2035 & unconditional: $13 \%$, conditional: $15 \%$ & Upper middle income \\
\hline Jordan & 2030 & unconditional: $1.5 \%$ conditional: $14.5 \%$ & Upper middle income \\
\hline Kingdom of Macedonia & 2030 & unconditional: $30 \%$, conditional: $36 \%$ & Upper middle income \\
\hline Kyrgyzstan & 2030 & $\begin{array}{l}\text { unconditional: } 11.49-13.75 \% \text { conditional: } \\
29-30.89 \%\end{array}$ & Upper middle income \\
\hline Lebanon & 2030 & unconditional: $15 \%$, conditional: $30 \%$ & \\
\hline Maldives & 2021-2030 & unconditional: $10 \%$, conditional: $20 \%$ & Upper middle income \\
\hline Mongolia & 2030 & $14 \%$ & Lower middle income \\
\hline Palestine & 2040 & unconditional: $12.8 \%$, conditional: $24.4 \%$ & $-*$ \\
\hline Philippines & 2030 & $70 \%$ & Lower middle income \\
\hline Sri Lanka & 2021-2030 & $\begin{array}{l}\text { energy industry emissions reduction of } 20 \% \\
\text { (BAU, unconditional } 4 \% \text {, conditional16\%) + } \\
\text { other industries reduce emissions by } 10 \%(3 \% \\
\text { unconditional3 } \% \text {, conditional7 } \%) \text {, total 30\% }\end{array}$ & Upper middle income \\
\hline Thailand & $2021-2030$ & unconditional: $20 \%$, conditional: $25 \%$ & Upper middle income \\
\hline Turkey & $2021-2030$ & $21 \%$ & Upper middle income \\
\hline Vietnam & $2021-2030$ & unconditional: $8 \%$, conditional: $25 \%$ & Upper middle income \\
\hline Yemen & $2020-2030$ & unconditional: $1 \%$, conditional: $14 \%$ & Low income \\
\hline
\end{tabular}

\section{(3) Fixed level targets, emission intensity targets, trajectory targets and policy action}

A minority of Belt and Road countries have committed to emission reduction targets in the form of fixed level targets, emission intensity targets, trajectory targets, and policy actions. 
As shown in Table 3, the NDC reports of three Belt and Road countries, namely Armenia, Bhutan, and Oman, revealed fixed level targets. When the fixed level targets are transferred into emission targets relative to 1990 emissions, it can be discovered that Armenia would reduce $24.8 \%$ emissions based on 1990 level, while Oman's emission will keep raising and the emission in 2030 will be 2.2 times of its 1990 level. Exceptionally, Bhutan is a net sink for emissions due to its huge areas of forest cover. Bhutan will remain carbon neutral in the future.

Table 3. Belt and Road countries with fixed level targets.

\begin{tabular}{clc}
\hline Country & \multicolumn{1}{c}{ Fixed Level Targets } & Income Group \\
\hline Armenia & $\begin{array}{l}\text { The total GHG emissions will be equivalent to } \\
633 \text { million } \mathrm{CCO}_{2} \text { equivalent between 2015-2050 }\end{array}$ & Upper middle income \\
\hline Bhutan & $\begin{array}{l}\text { Remain carbon neutral where emission of } \\
\text { greenhouse gases will not exceed carbon } \\
\text { sequestration by our forests, which is estimated } \\
\text { at 6.3 million tons of } \mathrm{CO}_{2}\end{array}$ & Lower middle income \\
\hline Oman & $\begin{array}{l}\text { Controlling its expected GHG emissions } \\
\text { growth by } 2 \%(2020-2030) \text { to } 88714 \mathrm{Gg}(2030)\end{array}$ & High income \\
\hline
\end{tabular}

As shown in Table 4, India, Israel, Malaysia, Turkmenistan, Singapore, and Uzbekistan adopted emission intensity targets. During the year 2015-2016, India planned to reduce its GDP carbon intensity by $33-35 \%$ relative to 2005 levels. Singapore has proposed to reduce its GDP carbon intensity from $0.176 \mathrm{~kg} \mathrm{CO}_{2} / \mathrm{S} \$$ (the value in 2005) to $0.113 \mathrm{~kg} \mathrm{CO}_{2} / \mathrm{S} \$$ by 2030.

Table 4. The emission intensity targets of selected Belt and Road countries.

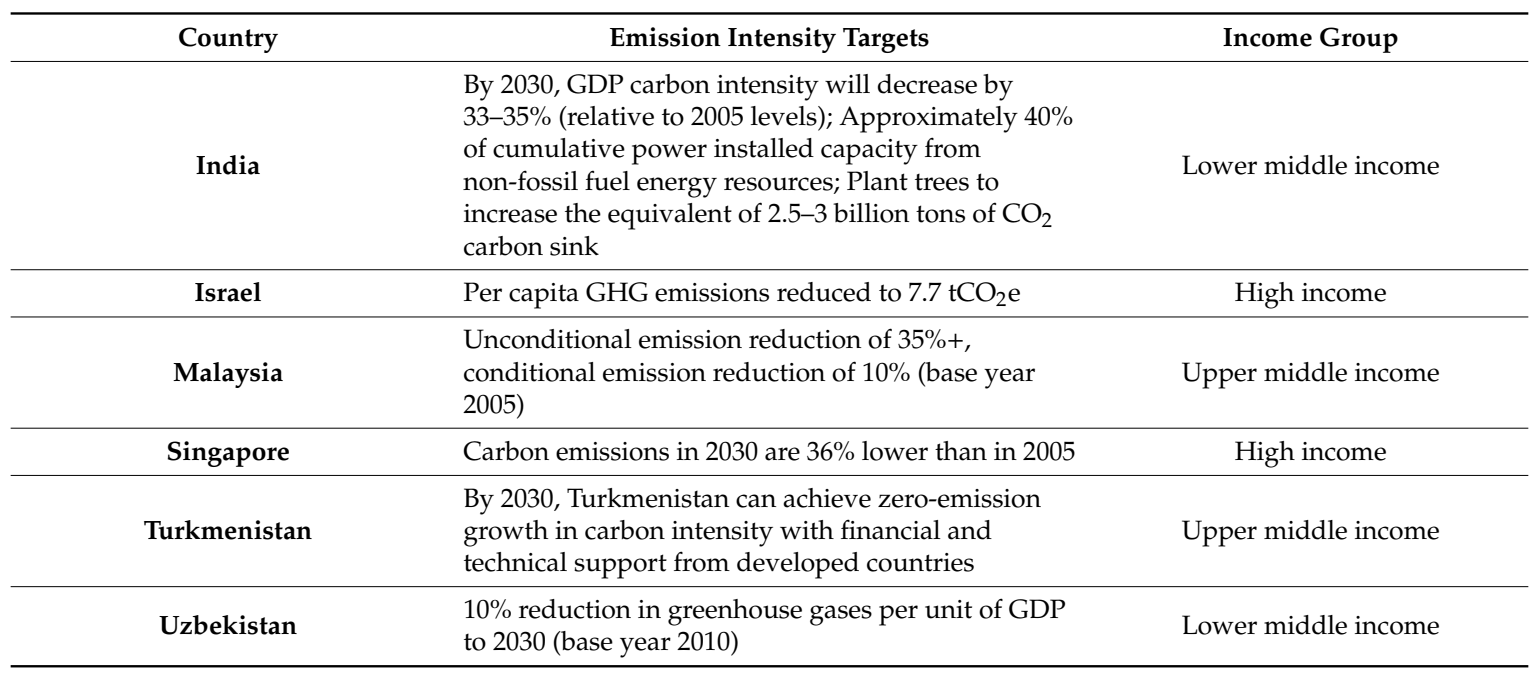

Of the 64 Belt and Road countries, Singapore is the only one that has addressed the issue of when carbon emissions will peak in the future, affirming its commitment to attain this peak around 2030. Although Singapore's emissions account for only $0.11 \%$ of global emissions, its commitments to emissions intensity and peak emissions stated in in its NDC report reflect a strong sense of responsibility in relation to its response to global climate change.

Ten countries, including Bahrain, Egypt, Kuwait, Laos, Myanmar, Qatar, Saudi Arabia, Nepal, United Arab Emirates, and Pakistan have only provided policy actions, with no quantitative mitigation targets in their NDC reports. For instance, Qatar has proposed its mitigation and adaptation actions in various sectors including energy, transport, and waste. Oil-exporting countries along the Belt and Road typically prefer to adopt this type of emission reduction target. Although the total emissions of 
these countries are not high, their per capita carbon emissions rank highest among the Belt and Road countries. Carbon reduction is, therefore, more challenging for these countries.

Figure 5 shows the distribution of the different types of emission reduction targets in the Belt and Road countries, as well as countries' income group in each type of emission reduction targets. These countries mainly focus on emission reduction relative to the base year and emission reductions relative to their baseline scenario targets, respectively accounting for $34.9 \%$ and $36.5 \%$ of all the Belt and Road countries. High income countries, especially those listed in Annex 1 of the Kyoto Protocol, tend to choose emission reduction targets relative to the base year, which is generally taken to be 1990 . Half of the countries with emission reductions relative to base year targets are high income countries, and more than fifty percent of high income countries along the Belt and Road adopted emission reduction relative to base year targets. Countries that are not as financially well-endowed, to say upper middle income countries and lower middle income countries along the Belt and Road, tend to choose emission reduction targets relative to their baseline scenario emissions, while emphasizing additional incentive targets relating to international support for emissions reductions. It can be verified by the constitute of countries with emission reduction relative to baseline scenarios targets, in which countries classified as high income countries and low income countries are only 1 and 2, respectively. Countries that emit large amounts of GHGs tend to choose carbon emission intensity targets to reduce emissions, whereas oil-producing countries with high income and high per capita emissions tend to take policy actions or to set emission intensity targets.

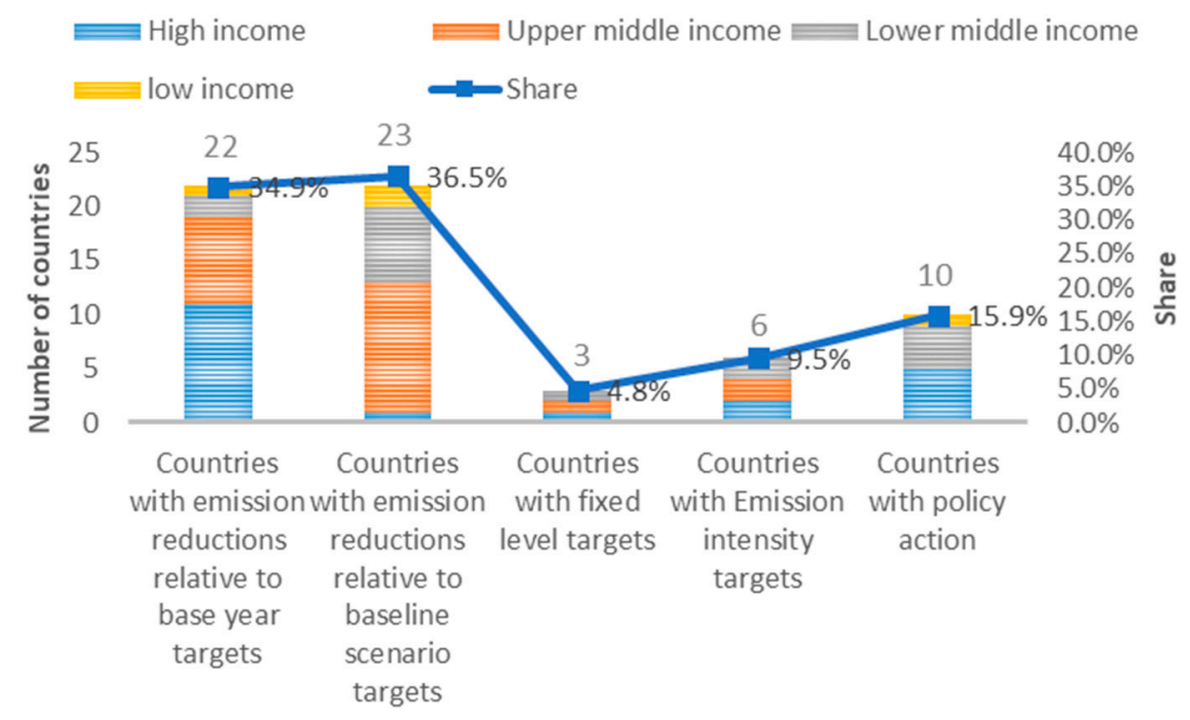

Figure 5. Share of the types of emission reduction targets of the Belt and Road countries and the distribution of various income groups in each emission reduction target group.

\subsection{An Analysis of Conditions of Emission Reduction}

The NCD goal is considered to reflect the autonomous behavior of a contracting party. However, because of differences in levels of economic development and in capabilities for responding to climate change among the Belt and Road countries, some countries have clearly stated their requirements for implementing emission reduction targets in their NDC reports. In this section, we analyze countries' conditions relating to their emissions reduction to determine how NDC will be implemented in the Belt and Road countries.

\section{(1) A comparison of conditional and unconditional emission reduction targets}

An analysis of the 64 Belt and Road NDC reports revealed that 15 countries, including Afghanistan, Pakistan, the Philippines, Bhutan, Oman, and India will only implement their own emission reduction activities if they receive international financial and technological support. In particular, India states 
"the successful implementation of NDC is contingent upon an ambitious global agreement including additional means of implementation to be provided by developed country parties, technology transfer, and capacity building" (http://www4.unfccc.int/submissions/INDC/Published\%20Documents/India/1/ INDIA \%20INDC\%20TO\%20UNFCCC.pdf). Although India is a major emitter of GHGs and a large developing country, emission reduction conditions are still emphasized.

As shown in Figure 6, 18 Belt and Road countries have simultaneously proposed conditional and unconditional emission reduction targets. The provision of international support will result in a significant increase in emission reductions in all of these countries, which may even exceed $100 \%$. For instance, Yemen's unconditional reduction of its emissions is only $1 \%$, whereas its conditional reduction of emissions is $14 \%$. Therefore, international assistance will greatly strengthen the motivation and capabilities of developing countries for reducing their emissions.

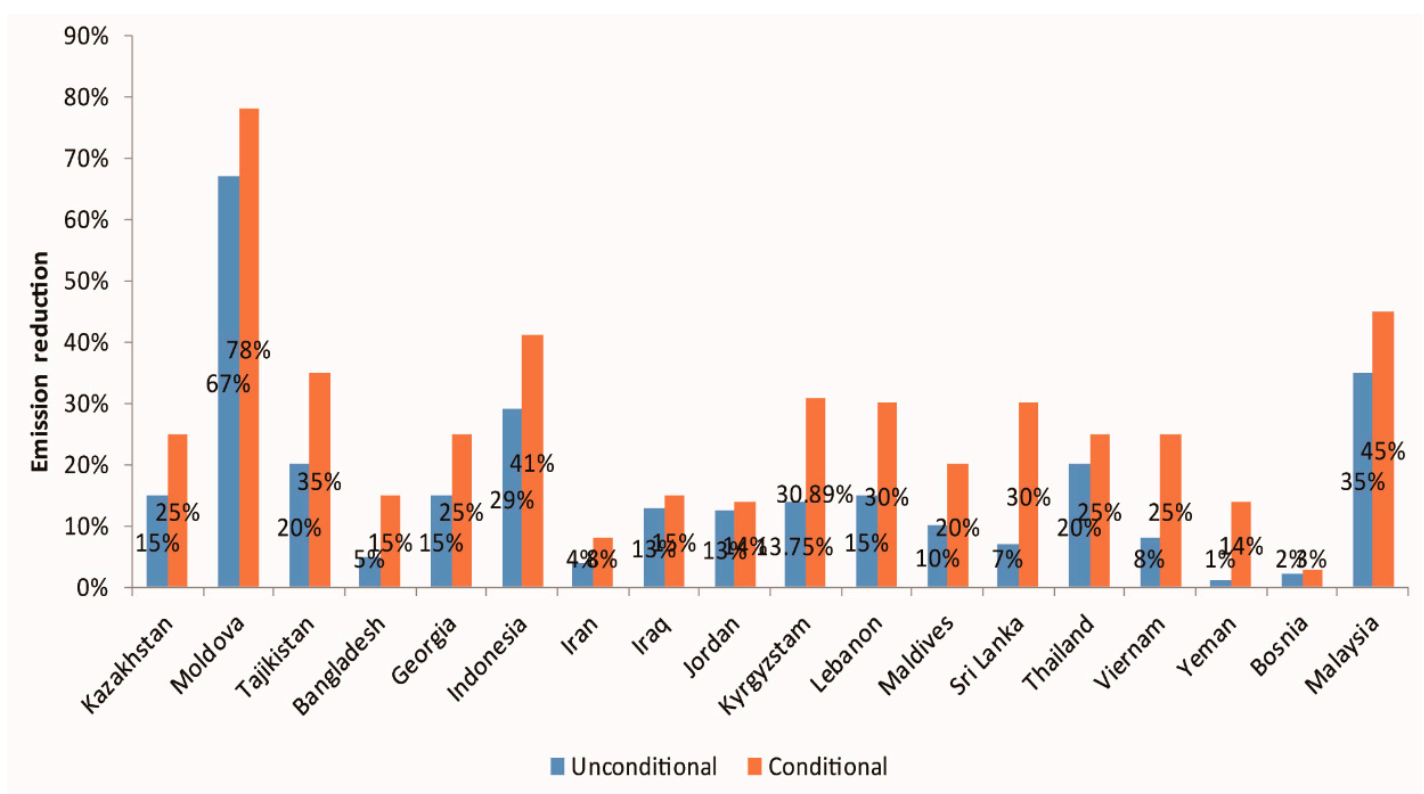

Figure 6. A comparison of proposed unconditional and conditional NDC emission reduction targets.

\section{(2) Technical demands for emission reduction}

As shown in Table 5, a further consideration in this study was the technological requirements for emission reduction proposed by Belt and Road countries in their NDC reports. The results of our analysis indicate that the technological requirements that featured most frequently in the reports were "GHG inventory accounting" and "data management, modeling and tools" followed by "technology transfer and development" and "vulnerability and adaptation assessments", "MRV ME systems", and "clean energy technology". Generally, Belt and Road countries are relatively less advanced in terms of their economies and available technologies. Therefore, their current requirements for basic capacity building to cope with climate change are extensive. The demand for assistance with GHG inventory preparation, accounting, and data management indicates that these countries would like to participate in international action on climate change but lack the capabilities to do so. Therefore, it is imperative for China to implement the Belt and Road green development initiative to strengthen the accounting and data management capabilities of participating countries to deal with climate change. Specific components of support include technical training relating to GHG inventory accounting, academic exchange, data management based on the Internet, and scientific research cooperation in the field of climate change. 
Table 5. Major technical needs articulated in the NDC reports of the Belt and Road countries.

\begin{tabular}{|c|c|c|c|c|c|c|c|c|c|c|c|c|}
\hline Country & $\begin{array}{c}\text { GHG } \\
\text { Inventory }\end{array}$ & $\begin{array}{l}\text { Institutional, } \\
\text { Law and } \\
\text { Policy } \\
\text { Support }\end{array}$ & $\begin{array}{c}\text { Data } \\
\text { Management, } \\
\text { Modeling } \\
\text { and Tools }\end{array}$ & $\begin{array}{c}\text { Capital } \\
\text { Mechanism } \\
\text { and Cost } \\
\text { Assessment }\end{array}$ & $\begin{array}{c}\text { Technology } \\
\text { Transfer \& } \\
\text { Development }\end{array}$ & $\begin{array}{l}\text { MRV a }^{\text {a }} \text { a }^{\mathrm{a}} \\
\text { System }\end{array}$ & $\begin{array}{l}\text { Vulnerability } \\
\text { and } \\
\text { Adaptation } \\
\text { Assessment }\end{array}$ & $\begin{array}{c}\text { Risk, } \\
\text { Management }\end{array}$ & $\begin{array}{l}\text { AFOLU a } \\
\text { Method }\end{array}$ & $\begin{array}{l}\text { Clean Energy } \\
\text { Measures }\end{array}$ & $\begin{array}{c}\text { Energy } \\
\text { Efficiency }\end{array}$ & $\begin{array}{c}\text { Water } \\
\text { Resources } \\
\text { Management }\end{array}$ \\
\hline Afghanistan & 0 & 0 & 1 & 0 & 0 & 0 & 1 & 1 & 1 & 1 & 1 & 1 \\
\hline Bangladesh & 1 & & 1 & 1 & 0 & 1 & 0 & 0 & 0 & 0 & 0 & 0 \\
\hline Cambodia & 0 & 0 & 0 & 0 & 1 & 1 & 0 & 0 & 0 & 0 & 0 & 0 \\
\hline India & 0 & 0 & 0 & 0 & 1 & 0 & 0 & 0 & 0 & 1 & 0 & 0 \\
\hline Laos & 0 & 0 & 1 & 0 & 0 & 0 & 0 & 0 & 0 & 1 & 0 & 0 \\
\hline Malaysia & 0 & 1 & 0 & 1 & 0 & 0 & 0 & 0 & 1 & 0 & 0 & 0 \\
\hline Nepal & 0 & 0 & 0 & 0 & 0 & 1 & 1 & 0 & 0 & 0 & 0 & 0 \\
\hline Pakistan & 1 & 0 & 1 & 0 & 1 & 0 & 0 & 0 & 0 & 0 & 0 & 0 \\
\hline Philippines & 0 & 0 & 0 & 0 & 1 & 0 & 1 & 1 & 0 & 1 & 1 & 1 \\
\hline Thailand & 0 & 0 & 1 & 0 & 0 & 0 & 0 & 1 & 1 & 1 & 1 & 1 \\
\hline Vietnam & 1 & 0 & 1 & 1 & 1 & 1 & 1 & 0 & 1 & 0 & 0 & 1 \\
\hline Albania & 1 & 0 & 0 & 0 & 0 & 0 & 0 & 0 & 0 & 0 & 0 & 0 \\
\hline Georgia & 1 & 0 & 0 & 0 & 1 & 1 & 0 & 0 & 0 & 0 & 0 & 0 \\
\hline Macedonia & 1 & 0 & 0 & 0 & 0 & 0 & 1 & 0 & 0 & 0 & 0 & 0 \\
\hline Moldova & 0 & 0 & 0 & 1 & 0 & 0 & 1 & 0 & 0 & 0 & 0 & 0 \\
\hline Serbia & 1 & 0 & 1 & 0 & 0 & 0 & 0 & 0 & 0 & 0 & 0 & 0 \\
\hline Total & 7 & 1 & 7 & 4 & 6 & 5 & 6 & 3 & 4 & 5 & 3 & 4 \\
\hline
\end{tabular}

Data Sources: Analysis of Intended Nationally Determined Contributions (INDCs), https://www.climatelinks.org/file/2104/download?token=ICW6yp8i. ${ }^{\text {: }}$ AFOLU: Agriculture, Forestry, and Other Land Use; MRV: Measurement, Reporting, and Verification; M\&E: Monitoring and Evaluation. 


\section{(3) Funding requirements for emission reduction}

With the exception of Annex I countries listed in Kyoto Protocol, all of the Belt and Road countries specified the need for abatement costs or financial assistance in their NDC reports. Twelve countries (Iran, Jordan, Egypt, India, Pakistan, Bangladesh, Afghanistan, Kyrgyzstan, Georgia, Moldova, Serbia, and Macedonia) have provided clear estimates of economic losses and costs of reducing emissions and have requested international assistance up to a total value of US $\$ 2.88$ trillion (Table 6). A further point to note is that the Belt and Road countries have devoted equal attention to climate change adaptation and mitigation in their NDC reports.

Table 6. Funding requirements of the Belt and Road countries, as stated in their NDC reports.

\begin{tabular}{|c|c|}
\hline Country & Abatement Costs or Funding Requirements \\
\hline Iran & $\begin{array}{l}\text { Unconditional emission reduction USD17.5 billion Conditional emission } \\
\text { reduction USD52.5 billion }\end{array}$ \\
\hline Jordan & USD5.7 billion \\
\hline Egypt & USD73 billion \\
\hline Indi & USD2.5 trillion (2015-2030) \\
\hline Pakistan & USD 40 billion \\
\hline Bengal & $\begin{array}{l}\text { Adaptation cost USD42 billion + Abatement cost USD27 billion } \\
\text { (2011-2030), total 共 USD } 69 \text { billion }\end{array}$ \\
\hline Afghanistan & $\begin{array}{l}\text { Adaptation cost USD } 10.785 \text { billion + Abatement cost USD } 6.62 \text { billion } \\
(2020-2030) \text {, 共 USD17.405 billion }\end{array}$ \\
\hline Kyrgyzstan & 1230.8 million \\
\hline Georgia & $\begin{array}{l}\text { Economic losses: no adaptation 10-12 billion USD, adaptation } 1.5-2 \\
\text { billion USD }\end{array}$ \\
\hline Moldova & $\begin{array}{l}\text { Conditional financial support USD4.9-5.1 billion, namely US\$327-340 } \\
\text { million per year; adaptation USD200 million }\end{array}$ \\
\hline Serbia & USD68 billion \\
\hline Macedonia & $\begin{array}{l}\text { Assistance: } 4.2 \text { billion Euros, Higher emission reduction targets are } 4.5 \\
\text { billion Euros }\end{array}$ \\
\hline Afghan & US $\$ 17.405$ billion (2020-2030) \\
\hline Cambodia & US $\$ 1.27$ billion (2020-2030) \\
\hline
\end{tabular}

\subsection{Coverage of Emission Sectors}

The key emission sectors vary by country because of economic and technological disparities. Carbon emissions can be effectively controlled only when emission reduction is carried out by these key sectors. Therefore, we analyzed the coverage of various sectors in relation to emission reduction in the NDC reports of the Belt and Road countries.

Energy, industrial processes and production use, agriculture, forestry and land-use changes, and waste are key sectors in these countries in accordance with the Guidelines for National Greenhouse Gas Inventories issued by the Intergovernmental Panel on Climate Change (IPCC) in 2016. Of these sectors, the energy industry ranked highest in terms of conservation and emission reduction. The NDC reports of 61 countries mention plans to reduce emissions in this sector. The only countries that have not mentioned energy reduction are Tajikistan, Belarus, and Bangladesh. The second most important sector mentioned in the reports was waste and its reduction. Relatively few countries have prioritized emission reductions in the agriculture and forestry sectors and in relation to land-use changes. A few countries have proposed to reduce emissions in their transportation and construction sectors. 
To determine whether national emission reduction plans cover domestic sectors responsible for large quantities of emissions, we compared the GHG emissions of five sectors across 64 countries in 2014 in terms of stated emission reductions in the NDC reports (Table A1). The five sectors were energy, industrial processes and production use, agriculture, waste, and forestry and land-use changes. Countries with the highest emissions in the five major accounting sectors, have formulated comprehensive emission reduction plans that cover their entire economies in their NDC reports. These countries are India, Russia, Indonesia, and Saudi Arabia. However, some countries, notably Bangladesh, have not covered their main GHG-emitting sectors in their NDC emission reduction plans. Table 7 shows the composition of GHG emissions for Bangladesh and this country's relative ranking among the Belt and Road countries in 2014. Evidently, whereas Bangladesh is among the top emitters among the Belt and Road countries in terms of its emissions in the sectors of agriculture, waste, and forestry and land-use changes, its NDC lacks any emission reduction plans for key GHG-emitting sectors, only covering those emanating from industrial and manufacturing processes, which are not particularly advanced.

Table 7. Major emission sources and coverage of these sectors in Bangladesh's nationally determined contribution (NDC) report.

\begin{tabular}{cccccc}
\hline & Energy & $\begin{array}{c}\text { Industrial } \\
\text { Process }\end{array}$ & Agriculture & $\begin{array}{c}\text { Land-Use Type Change } \\
\text { and Forestry }\end{array}$ & Waste \\
\hline $\begin{array}{c}\text { Emissions } \\
\left(\mathbf{M t C O}_{\mathbf{2}} \mathbf{)}\right.\end{array}$ & 66.44 & 9.25 & 74.59 & 29.22 & 18.76 \\
\hline Rank & 28 & 17 & 5 & 5 & uncover \\
\hline $\begin{array}{c}\text { NDC Sector } \\
\text { Coverage }\end{array}$ & uncover & cover & uncover & uncover & uncer \\
\hline
\end{tabular}

\section{Analysis of Future Emission Trends of Major GHG Emitters Among the Belt and Road Countries}

Global GHG emission data for 2014 (excluding emissions relating to forestry and land-use changes) showed that China, India, Russia, and Indonesia ranked first, fourth, fifth, and ninth, respectively, for their emissions globally. In 2014, these four countries collectively accounted for approximately $40 \%$ of global emissions and approximately $73 \%$ of the emissions of the Belt and Road countries. Given that the reduction of future GHG emissions through the implementation of the Belt and Road initiative has become imperative, we analyzed the future GHG emission trends for China, India, Russia, and Indonesia.

We first examined the emission reduction targets proposed by China, India, Russia, and Indonesia, and in their NDC reports, as shown in the first three columns in Table 8. China and India's emission reduction targets are based on diminishing carbon emission intensity, which can be primarily attributed to the large populations of both countries, their relatively low levels of economic development, and their positioning at an important stage of industrialization and rapid urbanization. Both countries are under tremendous pressure to control their GHG emissions. Setting a reduction target that relates to carbon emission intensity can promote a balance between economic growth and the reduction of carbon emissions, which is a reasonable path for developing countries to pursue in relation to emissions mitigation. Russia has adopted emission reduction targets relative to 1990. Considering the sharp decline in emissions caused by the collapse of the former Soviet Union in 1991, it will not be difficult for Russia to fulfil its commitment to reduce emissions in relation to its choice of 1990 as the base year. In recent years, Indonesia's emissions have risen dramatically because of the country's rapid economic growth. Indonesia's GDP has grown at an average annual rate of 5.5\% since 2010, and the government has adopted both unconditional and conditional targets for future emission reductions. According to its NDC report, Indonesia will be able to achieve $41 \%$ of its emission reduction targets with international support (https://www4.unfccc.int/sites/submissions/indc/Submission\%20Pages/submissions.aspx). 
Table 8. Emission reduction commitments made by China, India, Russia, and Indonesia in their nationally determined contribution (NDC) reports.

\begin{tabular}{|c|c|c|c|c|}
\hline & Target Year & Base Year & Emission Reduction Target & $\begin{array}{l}\text { Target Emission } \\
\quad\left(\mathrm{MtCO}_{2} \mathrm{e}\right)\end{array}$ \\
\hline China & 2030 & 2005 & $\begin{array}{l}\text { Carbon emissions peak; } \\
\text { Carbon emission intensity } \\
\text { decreased by } 60 \% \text { to } 65 \%\end{array}$ & $14,092.28-16,105.46$ \\
\hline India & 2030 & 2005 & $\begin{array}{l}\text { Carbon emission intensity } \\
\text { decreased by } 33 \% \text { to } 35 \%\end{array}$ & 9345.37-9632.92 \\
\hline Russia & 2030 & 1990 & $\begin{array}{l}\text { Emission reduction by } 25 \% \\
\text { to } 30 \%\end{array}$ & 2087.93-2237.07 \\
\hline Indonesia & 2030 & BAU & $\begin{array}{c}\text { Unconditional: } 29 \% \\
\text { conditional: } 41 \% \\
2030 \text { BAU emissions } 22,881 \\
\mathrm{MtCO}_{2} \mathrm{e}\end{array}$ & 2045.51-1699.79 \\
\hline
\end{tabular}

The emissions in 2030 have to be determined to allow portrayal of the future emission pathway of each country. For China and India, which have proposed emission intensity reduction targets, the IEA's World Energy Outlook 2014 [17] assumptions for China and India's economic growth rate in the non-policy scenario were adopted. A $6.9 \%$ and a $5.3 \%$ growth rate was assumed for China's GDP growth for 2012 to 2020 and 2020 to 2030, respectively, whereas a $6.6 \%$ growth rate was assumed for India's GDP growth in 2020 to 2030. For Indonesia, the BAU emissions in 2030 have been given in its NDC report as 22,881 $\mathrm{MtCO}_{2} \mathrm{e}$. Each country's emission targets in 2030 are shown in the last column of Table 8. Taking emissions of China, India, Russia, and Indonesia in 2014 and 2030 as two endpoints, the future emission reduction pathway of each country was obtained under the condition of constant reduction rate, as shown in Figure 7. China's emissions are projected to slow down by 2030. Given the commitment made by the Chinese government to reach the peak of carbon emissions as early as 2030, the downward trend of China's carbon emissions is expected to be more significant than the trajectory depicted in Figure 8. Russia's emissions will demonstrate the least growth and their reduction will be no difficult to achieve. India's and Indonesia's emissions will continue to rise rapidly by 2030. The targeted economic growth rates and emission reduction commitments of India and Indonesia indicate that their respective emissions will be 3 and 2.5 times higher in 2030 than their 2014 levels. Indonesia's emissions raise particular concern, given that the country's total GHG emissions, including carbon emissions produced in the forestry sector and through land-use changes (accounting for $68 \%$ of the total emissions), reached $2441.64 \mathrm{MtCO}_{2} \mathrm{e}$ in 2014. Consequently, Indonesia should pay more attention to changes in land use and reduce carbon emissions in the forestry sector.

Based on the future emission pathways of China, India, Russia, and Indonesia, the aggregate emissions of these four countries in 2030 were estimated to be between 28.03 and $30.20 \mathrm{GtCO}_{2} \mathrm{e}$. Compared with the global NDC emission pathway to 2030 estimated by UNFCCC, which shows the implementation of the global communicated NDCs will result in the global emission levels of 55.0 (51.4-57.3) $\mathrm{GtCO}_{2} \mathrm{e}$ in 2025 and 56.2 (52.0-59.3) $\mathrm{GtCO}_{2} \mathrm{e}$ in 2030 [18], the tendency of the global emissions should slow after 2025, whereas the growth rate of the aggregate emissions of China, India, Russia, and Indonesia will keep increasing with an annual growth rate of around 3\% (Figure 8). The ratio of the aggregate emissions of China, India, Russia, and Indonesia to world emissions during 2015-2030 also exhibits a significant increase from 37.33\% in 2015 to $50.93-53.90 \%$ in 2030 . Therefore, from a global perspective, the emissions of the top four countries in the Belt and Road are still facing enormous pressure to reduce emissions, even though they are also facing tremendous pressure from population increase and economic development. For these countries, the question of how to balance the reduction of emissions and the economic growth is likely to remain a long-term dilemma. 

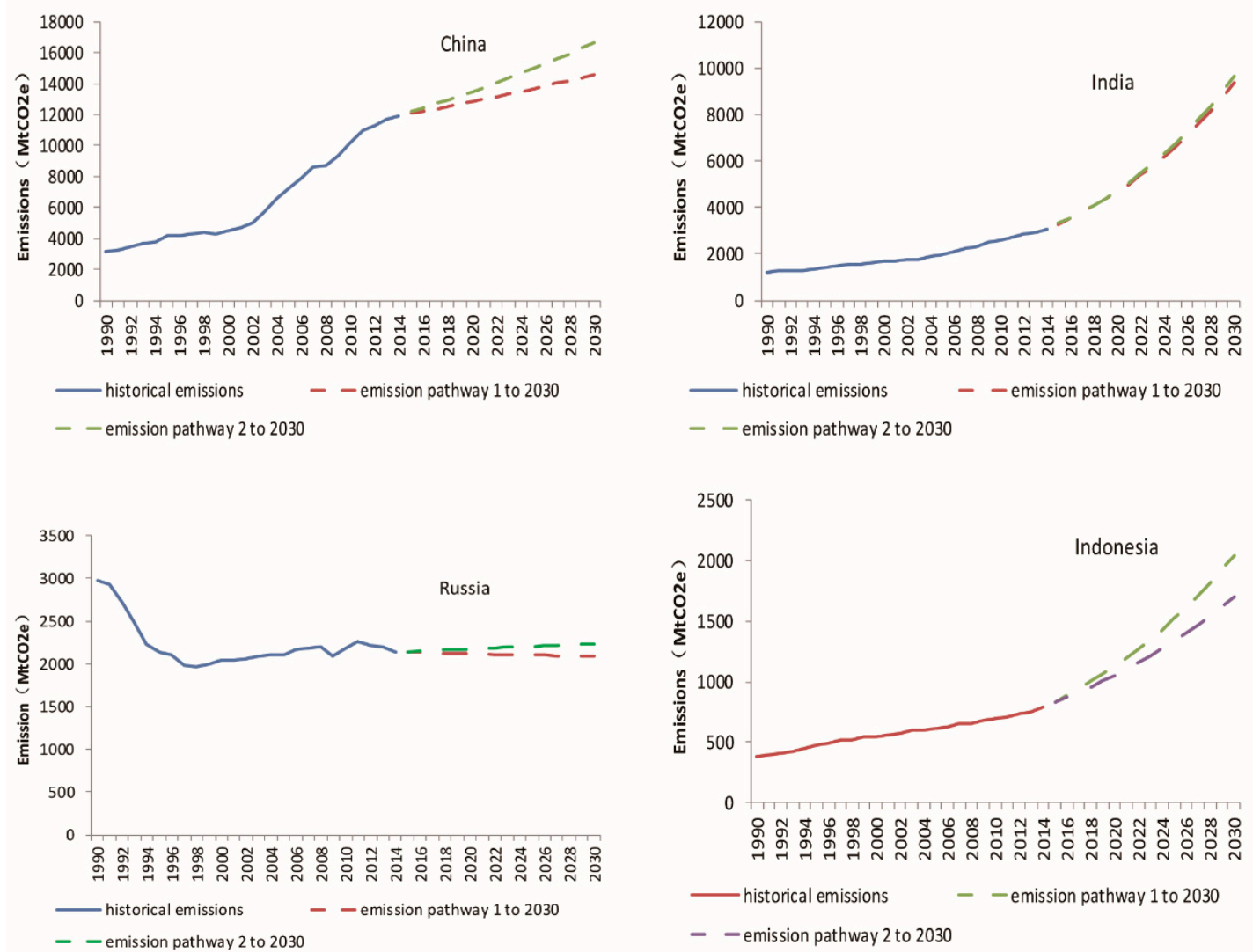

Figure 7. Carbon emissions pathways for China, India, Russia, and Indonesia.

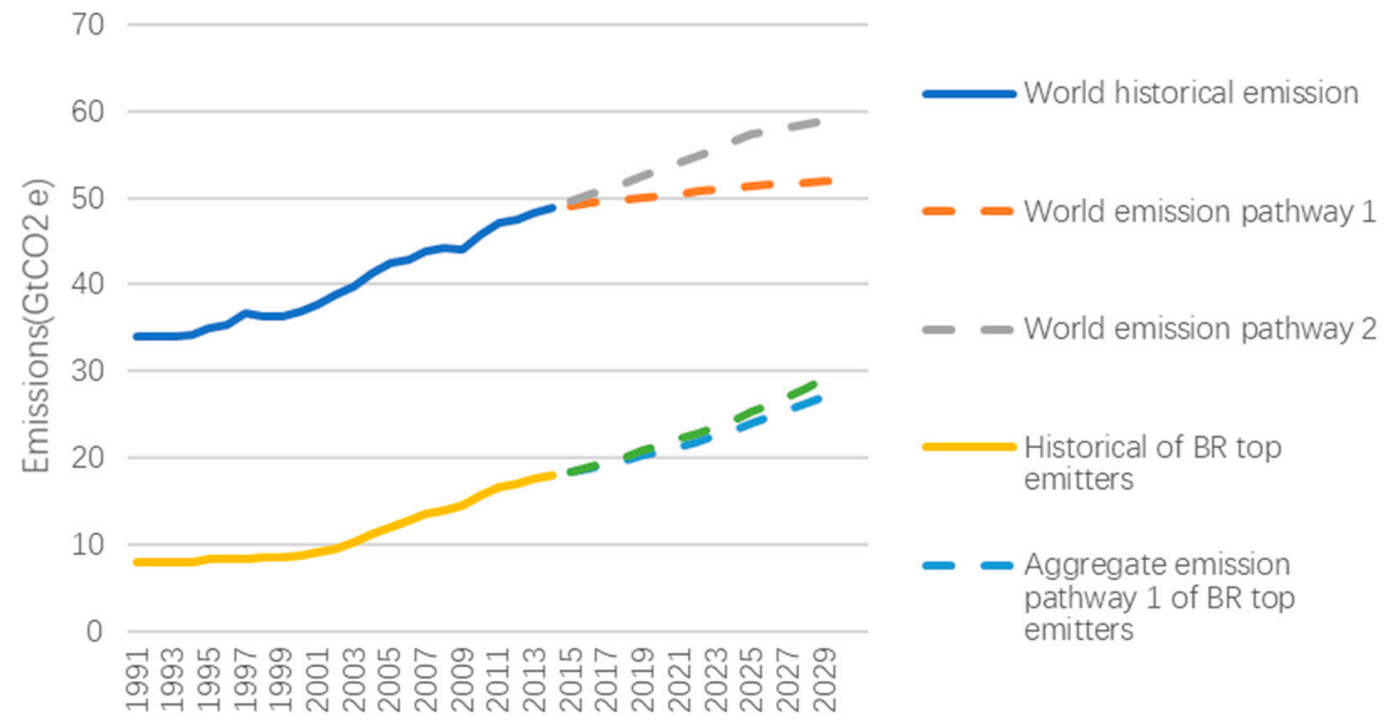

Figure 8. Comparison of future emission pathways between the world total and the aggregate emissions of China, India, Russia, and Indonesia (BR top emitters).

\section{Summary and Discussion}

The GHG emissions of the Belt and Road countries are currently on the rise, and their emission efficiencies are relatively low. Of these countries, India, Indonesia, and Russia are among the top GHG emitters and are the key target areas within the Belt and Road initiative to reduce emissions. Our analysis of the NDC reports of the Belt and Road countries revealed that about $70 \%$ of these countries have chosen future emission reduction targets that are relative to the base year and to their baseline 
scenario emissions. Countries that are extensive GHG emitters, such as India, have tended to favor reductions of their carbon intensity. Given variations in their economic and technological conditions, approximately half of the Belt and Road countries have stated that they require technical and financial support. The most commonly identified technological requirements were GHG inventory accounting, and data management modeling and tools. The total amount of financial support explicitly requested in the NDC reports of the Belt and Road countries to enable them to achieve considerably higher emission reduction targets amounts to US $\$ 2.88$ trillion. If international financial and technology aid is met, the motivation and capabilities of developing countries regarding emission reduction will be greatly enhanced, and their emission reduction rates will increase significantly. Of the key industrial sectors, the energy industry accounted for the highest emission reduction coverage, while coverage of forestry and land-use change and agriculture was relatively lower in terms of emission reduction. Our findings further reveal that the emission reduction commitments stated in the NDC reports of some countries do not cover their key emission sectors.

Among the four Belt and Road countries responsible for the greatest quantities of GHG emissions, China and Russia have committed to unconditional emission reduction targets. India has asserted that it will only fulfill its emission reduction commitments if "an ambitious global agreement including additional means of implementation to be provided by developed country parties, technology transfer and capacity building" for this purpose. Indonesia has proposed two emission reduction targets, one conditional and one unconditional. In the future, Indonesia's carbon emission reduction efforts should focus on the forestry sector and land-use changes. On the whole, emissions from China and Russia can be expected to demonstrate a constant or declining trend in the future, but emissions from India and Indonesia will continue to rise. However, from the perspective of global emission reduction, the share of the four countries' emissions in 2030 will account for more than $50 \%$ of the global emissions indicating the importance of balanced emission reduction and economic growth for these countries.

In light of our analysis of the NDC reports of the Belt and Road countries, especially the results obtained in Section 3.2 considering Belt and Road countries' technological and financial requirements, we recommend that China takes the following measures to advance this international initiative to promote green development within these countries. First, the capabilities of Belt and Road countries relating to the deployment of technology for emission inventory accounting should be developed to enhance their participation in global climate change action. Second, an "Internet Plus (Internet Plus means to combine the Internet with traditional industries to promote industry development in all fields)" platform should be constructed for managing and utilizing low-carbon data management and utilization. A green data-sharing platform can be created as a result of efforts to strengthen the capabilities of Belt and Road countries to data management, modeling, and evaluation. Third, exchanges of low-carbon and green technologies among the Belt and Road countries should be strengthened to improve the emission efficiency. Fourth, China's various investment projects in the Belt and Road countries should be fully integrated with these countries' national emission reduction targets and low-carbon development plans to enhance collaborative outputs. Finally, to assist these countries to reduce their emissions, financial assistance, as requested in their NDC reports, should be increased through the incorporation of financial plans developed by agencies such as the Asian Infrastructure Investment Bank and the BRICS New Development Bank.

In addition, because the focus of this paper was on NDC reports, the economic growth trend of each Belt and Road country was not discussed in detail, which may also contribute significantly to each country's future emissions. Factors such as the relations between emission reduction targets with GDP growth, population growth, and the share of GDP of industry should be investigated. An emission and economy integrated dynamic model may also be established for the Belt and Road countries, which requires further research.

Author Contributions: Conceptualization, J.W., Q.Z.; Data curation, G.K., Y.C.; Formal analysis, G.K.; Writing—original draft, J.W., G.K.; Writing—review \& editing, J.W., X.W.; Project administration W.Z. 
Funding: This research was funded by the National Key R\&D Plan Program of China No. 2016YFA0602703, National Science Foundation of China No. 41871219.

Acknowledgments: We thank Radhika Johari and Alex Boon, PhD, from Liwen Bianji, Edanz Editing China (www.liwenbianji.cn/ac), for editing the English text of a draft of this manuscript. The authors also would like to thank the editor and anonymous reviewers for their insightful and constructive comments.

Conflicts of Interest: The authors declare no conflict of interest.

\section{Appendix A}

Table A1. Emissions of national sectors and coverage of emission reduction in the NDC reports of the Belt and Road countries.

\begin{tabular}{|c|c|c|c|c|c|}
\hline Country & Energy & $\begin{array}{l}\text { Industrial Processes } \\
\text { and Product Use }\end{array}$ & Agriculture & $\begin{array}{l}\text { LULUCF and } \\
\text { Forestry }\end{array}$ & Waste \\
\hline Afghanistan & 50.00 & $(59.00) *$ & 21.00 & $(23.00)$ & 18.00 \\
\hline Albania & 60.00 & 49.00 & $(41.00)$ & 41.00 & $(53.00)$ \\
\hline Armenia & 58.00 & 56.00 & $(52.00)$ & 36.00 & 51.00 \\
\hline Azerbaijan & 29.00 & $(41.00)$ & 32.00 & $(53.00)$ & 36.00 \\
\hline Bahrain & 35.00 & (50.00) & $(63.00)$ & $(32.00)$ & $(30.00)$ \\
\hline Bangladesh & $(28.00)$ & 17.00 & $(5.00)$ & $(5.00)$ & $(9.00)$ \\
\hline Belarus & $(30.00)$ & 30.00 & 19.00 & $(40.00)$ & 20.00 \\
\hline Bhutan & 64.00 & $(60.00)$ & 57.00 & 49.00 & 64.00 \\
\hline Bosnia \& Herzegovina & 42.00 & 44.00 & 44.00 & 18.00 & 41.00 \\
\hline Brunei & 44.00 & $(61.00)$ & $(61.00)$ & 15.00 & $(62.00)$ \\
\hline Bulgaria & 32.00 & 33.00 & 37.00 & 54.00 & 27.00 \\
\hline Cambodia & 53.00 & 54.00 & $(20.00)$ & 8.00 & 58.00 \\
\hline Croatia & 46.00 & 34.00 & 45.00 & 50.00 & 44.00 \\
\hline Cyprus & 57.00 & 58.00 & 60.00 & 39.00 & 59.00 \\
\hline Czech Republic & 23.00 & 25.00 & 33.00 & 56.00 & 31.00 \\
\hline Egypt & 16.00 & 8.00 & 13.00 & $(38.00)$ & 7.00 \\
\hline Estonia & 43.00 & 62.00 & 42.00 & 13.00 & 52.00 \\
\hline Georgia & 51.00 & 39.00 & 43.00 & 21.00 & 34.00 \\
\hline Greece & 26.00 & 24.00 & 25.00 & 42.00 & 33.00 \\
\hline Hungary & 33.00 & 29.00 & 30.00 & 14.00 & 29.00 \\
\hline India & 1.00 & 1.00 & 1.00 & 2.00 & 3.00 \\
\hline Indonesia & 5.00 & 6.00 & 2.00 & 1.00 & 2.00 \\
\hline Iran & 3.00 & 4.00 & 11.00 & 4.00 & 8.00 \\
\hline Iraq & 10.00 & 19.00 & 24.00 & $(47.00)$ & 16.00 \\
\hline Israel & 27.00 & 14.00 & 51.00 & $(35.00)$ & 19.00 \\
\hline Jordan & 38.00 & 32.00 & 54.00 & 23.00 & 28.00 \\
\hline Kazakhstan & 12.00 & $(21.00)$ & 18.00 & 17.00 & 25.00 \\
\hline Kuwait & 15.00 & 22.00 & 58.00 & $(34.00)$ & 45.00 \\
\hline Kyrgyzstan & 52.00 & 52.00 & 39.00 & 43.00 & 50.00 \\
\hline Laos & 62.00 & $(48.00)$ & $(26.00)$ & 9.00 & $(56.00)$ \\
\hline Latvia & 55.00 & 45.00 & 40.00 & 55.00 & 48.00 \\
\hline Lebanon & 41.00 & 28.00 & 56.00 & 31.00 & 37.00 \\
\hline Lithuania & 49.00 & 37.00 & 38.00 & 16.00 & 40.00 \\
\hline Macedonia, FYR & 56.00 & $(40.00)$ & $(53.00)$ & $(23.00)$ & $(46.00)$ \\
\hline Malaysia & 13.00 & 10.00 & 22.00 & 63.00 & 4.00 \\
\hline Maldives & 63.00 & 64.00 & $(64.00)$ & $(22.00)$ & 63.00 \\
\hline Moldova & 54.00 & 51.00 & 48.00 & 44.00 & 42.00 \\
\hline
\end{tabular}


Table A1. Cont.

\begin{tabular}{|c|c|c|c|c|c|}
\hline Country & Energy & $\begin{array}{l}\text { Industrial Processes } \\
\text { and Product Use }\end{array}$ & Agriculture & $\begin{array}{l}\text { LULUCF and } \\
\text { Forestry }\end{array}$ & Waste \\
\hline Mongolia & 45.00 & 63.00 & 17.00 & $(7.00)$ & 60.00 \\
\hline Montenegro & 61.00 & 57.00 & 59.00 & (19.00) & 61.00 \\
\hline Myanmar & 37.00 & $(55.00)$ & 6.00 & 3.00 & 11.00 \\
\hline Nepal & 48.00 & $(43.00)$ & $(16.00)$ & 11.00 & $(49.00)$ \\
\hline Oman & 20.00 & 31.00 & $(49.00)$ & $(33.00)$ & 47.00 \\
\hline Pakistan & 19.00 & 11.00 & 3.00 & 6.00 & 21.00 \\
\hline Philippines & 21.00 & 12.00 & 9.00 & 60.00 & 12.00 \\
\hline Poland & 7.00 & 15.00 & 12.00 & 59.00 & 17.00 \\
\hline Qatar & 24.00 & 27.00 & 55.00 & 23.00 & 57.00 \\
\hline Romania & 25.00 & $(18.00)$ & $(23.00)$ & $(64.00)$ & 24.00 \\
\hline Russian Federation & 2.00 & 2.00 & 4.00 & 62.00 & 1.00 \\
\hline Saudi Arabia & 4.00 & 5.00 & 29.00 & 23.00 & 6.00 \\
\hline Serbia & 34.00 & $(38.00)$ & $(31.00)$ & $(46.00)$ & $(32.00)$ \\
\hline Singapore & 14.00 & 23.00 & 62.00 & 20.00 & 38.00 \\
\hline Slovakia & 36.00 & 35.00 & 46.00 & 51.00 & 35.00 \\
\hline Slovenia & 47.00 & 47.00 & 50.00 & 52.00 & 55.00 \\
\hline Sri Lanka & 40.00 & 46.00 & 35.00 & 12.00 & 10.00 \\
\hline Syria & 31.00 & 26.00 & $(34.00)$ & 45.00 & 22.00 \\
\hline Tajikistan & $(59.00)$ & 53.00 & 36.00 & 23.00 & $(54.00)$ \\
\hline Thailand & 9.00 & 9.00 & 7.00 & 10.00 & 13.00 \\
\hline Turkey & 6.00 & 3.00 & 10.00 & 61.00 & 5.00 \\
\hline Turkmenistan & 22.00 & 36.00 & 27.00 & $(23.00)$ & 43.00 \\
\hline Ukraine & 8.00 & 13.00 & 14.00 & 48.00 & 14.00 \\
\hline United Arab Emirates & 11.00 & $(16.00)$ & $(47.00)$ & $(37.00)$ & 26.00 \\
\hline Uzbekistan & 17.00 & 20.00 & 15.00 & 57.00 & 23.00 \\
\hline Vietnam & 18.00 & $(7.00)$ & 8.00 & 58.00 & 15.00 \\
\hline Yemen & 39.00 & 42.00 & 28.00 & 23.00 & 39.00 \\
\hline
\end{tabular}

*: Numbers in the table indicate the rankings of emissions from different industries in the Belt and Road countries, while values in parentheses indicate that the emission reduction from the corresponding sector is not covered in that country's NDC report.

\section{References}

1. Ding, J.G.; Zhang, C. The Construction of "Belt and Road Initiative" and International Climate Governance. Mod. Int. Rel. 2018, 9, 53.

2. Bataille, C.; Waisman, H.; Colombier, M.; Colombier, M.; Segafredo, L.; Williams, J.; Jotzo, F. The need for national deep decarbonization pathways for effective climate policy. Clim. Policy 2016, 16 (Suppl. 1), S7-S26. [CrossRef]

3. den Elzen, M.; Kuramochi, T.; Höhne, N.; Cantzler, J.; Esmeijer, K.; Fekete, H.; Fransen, T.; Keramidas, K.; Roelfsema, M.; Sha, F.; et al. Are the G20 economies making enough progress to meet their NDC targets? Energy Policy 2019, 126, 238-250. [CrossRef]

4. Hof, A.F.; den Elzen, M.G.J.; Admiraal, A.; Roelfsema, M.; Gernaat, D.E.H.J.; van Vuuren, D.P. Global and regional abatement costs of Nationally Determined Contributions (NDCs) and of enhanced action to levels well below $2{ }^{\circ} \mathrm{C}$ and $1.5^{\circ} \mathrm{C}$. Environ. Sci. Policy 2017, 71, 30-40. [CrossRef]

5. Fragkos, P.; Fragkiadakis, K.; Paroussos, L.; Pierfederici, R.; Vishwanathan, S.S.; Köberle, A.C.; Lyer, G.; He, C.M.; Oshiro, K. Coupling national and global models to explore policy impacts of NDCs. Energ. Policy 2018, 118, 462-473. [CrossRef]

6. Wang, L.; Yang, L.; Chen, W.Y.; Shen, B.G.; Zhang, C.L.; Yin, S. Assessment of carbon reduction effect of the Nationally Determined Contributions. Clim. Chang. Res. 2018, 14, 613-620.

7. Wu, J.; Wang, S.Q.; Wang, Z. The analysis of the evolution of climate negotiating positions and future emission targets in major countries. Clim. Chang. Res. 2016, 12, 1673-1719. 
8. Fan, J.L.; Da, Y.B.; Wan, S.L.; Zhang, M.; Cao, Z.; Wang, Y.; Zhang, X. Determinants of carbon emissions in 'Belt and Road Initiative' countries: A production technology perspective. Appl. Energy 2019, 239, 268-279. [CrossRef]

9. Fu, J.Y.; Si, X.M. Driving Factors of Carbon Emission of the Countries along "the Belt and Road", Their Potential and Contribution to the Emission Reduction. Trop. Geogr. Med. 2017, 37, 1-9.

10. Wu, N.; Fu, Z.Q.; Wang, Y.H.; He, C.; Feng, Q. EKC test and decoupling analysis of carbon emissions in countries along the "One Belt and One Road". J. Environ. Eng. Tech. 2018, 8, 98-105.

11. Xu, R.N.; Wu, Y.M. How Culture Affects Carbon Emissions in Countries along the Belt and Road Route? An Empirical Analysis under the Framework of the EKC. Ecol. Econ. 2018, 7, 14-19.

12. Liu, Y.; Hao, Y. The dynamic links between $\mathrm{CO} 2$ emissions, energy consumption and economic development in the countries along "the Belt and Road". Sci. Total Environ. 2018, 645, 674-683. [CrossRef] [PubMed]

13. WRI, CAIT Climate Data Explorer. CAIT Paris Contributions Map; World Resources Institute: Washington, DC, USA, 2016; Available online: http://cait.wri.org/indcs/ (accessed on 12 March 2018).

14. Liu, P.L. The characteristics and lessons of urbanization in India. Urban Rural Dev. 2010, 10, 76-78.

15. Lin, M. The Process of Indonesian Industrialization and the Evolution of Industry Policy. Southeast Asia 2011, $6,11-15$.

16. Zhang, H.B. India: A Dramatic Role in the International Negotiation on Climate Change. World Environ. 2009, 1, 30-33.

17. IEA (International Energy Agency). World Energy Outlook; OECD/IEA: Paris, France, 2014; p. 41.

18. UNFCCC, 2016. Aggregate Effect of the Intended Nationally Determined Contributions: An Update. Available online: https:/unfccc.int/process/the-paris-agreement/nationally-determined-contributions/ synthesis-report-on-the-aggregate-effect-of-intended-nationally-determined-contributions (accessed on 23 February 2018).

(C) 2019 by the authors. Licensee MDPI, Basel, Switzerland. This article is an open access article distributed under the terms and conditions of the Creative Commons Attribution (CC BY) license (http://creativecommons.org/licenses/by/4.0/). 